\title{
PENGETAHUAN PERAWAT TENTANG PRIMARY SURVEY (PENILAIAN AWAL) PADA PASIEN GAWAT DARURAT DI INSTALASI GAWAT DARURAT (IGD)
}

\author{
Marlisa \\ Jurusan Keperawatan Poltekkes Medan
}

\begin{abstract}
Abstrak
Primary Survey (Penilaian Awal) merupakan usaha yang dilakukan untuk mempertahankan kehidupan pada saat pasien atau korban mengalami keadaan yang mengancam jiwa, Kepedulian perawat pada saat menemukan klien yang membutuhkan primary survey (penilaian awal) sangat mempengaruhi keberhasilan usaha pertolongan yang akan di lakukan. Perawat di tuntut memiliki pengetahuan dan sikap yang baik kepada semua intervensi dalam pelayanan di Rumah sakit khususnya primary survey (penilian awal) yang menyangkut kehidupan klien. Tujuan penelitian untuk mengetahui pengetahuan perawat tentang primary survey (penilaian awal) pada pasien gawat darurat di instalasi gawat darurat (IGD) RSUD Dr.pirngadi medan 2017, penelitian ini menggunakan metode deskriptif dengan desain penelitian cross sectional dengan menggunakan tehnik total sampling dengan jumlah responden 30 orang perawat yang bekerja di instalasi gawat darurat RSUD.Dr.pirngadi medan tahun 2017. Hasil penelitian yang dilakukan pada 30 orang responden diperoleh bahwa pengetahuan perawat dalam primary survey (penilaian awal) di instalasi gawat darurat (IGD) RSUD. Dr.pirngadi medan tahun 2017 meliputi perawat berpengetahuan baik yaitu berpengetahuan baik dalam primary survey (penilaian awal) yaitu sebanyak 19 responden (63,3\%), pengetahuan cukup sebanyak 11 responden $(36,7 \%)$, dan tidak ditemukan responden dengan pengetahuan kurang. Berdasarkan pendidikan, mayoritas berpengetahuan baik yaitu responden yang berlatar belakang berpendidikan SI keperawatan sebanyak 12 responden (100\%), dan berpengetahuan cukup yaitu responden yang berpendidikan DIII keperawatan sebanyak 11 responden $(61,1 \%)$. Berdasarkan umur, mayoritas responden yang berpengetahuan baik yaitu umur 31-35 tahun 6 responden (60,0\%), berpengetahuan cukup umur $>40$ tahun sebanyak 2 responden $(28.6 \%)$. Berdasarkan masa kerja, mayoritas responden yang berpengetahuan baik yaitu masa kerja $>10$ tahun sebanyak 5 responden $(100 \%)$, berpengetahuan cukup masa kerja 1-5 tahun sebanyak 9 responden (64,3\%). Dengan pengetahuan yang baik diharapkan pelayanan pada pasien terutama pada pasien kondisi kritis (Darurat) dapat dilakukan dengan tepat, cepat, cermat dan efisien. Demi terlaksananya pelayanan holistik perawat harus selalu meningkatkan pengetahuan (diperbaharui secara berkala) agar tujuan akhir meningkatkan harapan hidup pasien dan mencegah kecacatan tercapai.
\end{abstract}

Kata Kunci : pengetahuan, primary survey

\section{LATAR BELAKANG}

Kecelakaan di jalan raya masih menjadi masalah serius di Negara berkembang dan negara maju. Angka kematian menurut World Health Organization (WHO, 2004) telah mencapai 1.170 .649 orang di seluruh dunia. Jumlah setara dengan 2,2\% dari jumlah kematian di dunia dan menempati urutan kesembilan dari kesepuluh penyebab kematian. Angka kecelakaan lalu lintas di dunia selalu meningkat pada tahun 2020, diperkirakan kecelakaan lalu lintas akan menjadi penyebab kematian nomor tiga setelah jantung iskemik dan depresi dengan proyeksi kecelakaan dari 5,1 juta pada tahun 1990 menjadi 8,4 juta pada tahun 2020. Presentasi keterlibatan sepeda motor dalam kecelakaan di jalan, sebanyak $70 \%$ dan $30 \%$ roda empat. Hasil dan tuntutan kebutuhan tersebut diantaranya meluncurkan jenis kendaraan yang beragam hingga melahirkan satu masalah yang cukup mengancam bagi kehidupan manusia yakni kecelakaan lalu lintas yang menyebabkan trauma pada fisik manusia. (Badan Intelijen Nasional, 2013)

Kejadian gawat darurat biasanya berlangsung cepat dan tiba-tiba sehingga sulit memprediksi kapan terjadinya. Langkah terbaik untuk situasi ini adalah waspada dan melakukan upaya kongkrit untuk mengantisipasinya. Harus di pikirkan suatu bentuk mekanisme bantuan kepada korban dari awal tempat kejadian, selama perjalanan menuju sarana kesehatan, bantuan fasilitas kesehatan sampai paska kejadian cedera. (Rahmanta, 2014)

Kegawatdaruratan merupakan layanan keperawatan yang komperhensif diberikan pada pasien dengan injuri akut atau mengancam kehidupan. kegawatdaruratan dapat terjadi pada daerah yang sulit dijangkau petugas kesehatan, maka pada kondisi tersebut peran serta masyarakat untuk membantu korban sebelum 
ditemukan oleh petugas kesehatan menjadi sangat penting. (Sudiharto \& Sartono, 2011)

Penanganan gawat darurat tetap memegang prinsip Do Not Further Harm, Artinya jangan memperberat keadaan penderita. Hal ini mengingatkan pada kondisi tersebut pasien dapat kehilangan nyawa hanya dalam hitungan menit saja. Berhenti nafas selama 23 menit pada manusia dapat menyebabkan kematian yang fatal. (Gadar Medik Indonesia, 2016)

Instalasi Gawat Darurat (IGD) adalah instalasi untuk menangani kasus gawat darurat seperti, panas dan muntah-muntah, diare berat, kecelakaan, keracunan, korban bencana alam yang membutuhkan penanganan segera untuk menyelamatkan nyawa dan menghindari kecacatan. (Wicaksana, 2008)

Penilaian awal korban cedera kritis akibat cedera multiple merupakan tugas yang menantang, dan tiap menit bisa berarti hidup atau mati. Sistem pelayanan tanggap darurat ditujukan untuk mencegah kematian dini (early) karena trauma yang bisa terjadi dalam beberapa menit hingga beberapa jam sejak cedera (kematian segera karena trauma, immediate, terjadi saat trauma). Perawatan kritis, intensif, ditujukan untuk menghambat resiko kecacatan dan bahkan kematian. Hal ini bisa saja terjadi karena trauma yang terjadi dalam beberapa hari hingga beberapa minggu setelah trauma tidak mendapatkan penanganan yang optimal. Berdasarkan kasus diatas, Primary Survey (penilaian awal) dan secondary survey (penilaian akhir) merupakan salah satu item kegawatdaruratan yang sangat mutlak harus dilakukan untuk mengurangi resiko kecacatan, bahkan kematian.

Secondary survey dikerjakan untuk memeriksa lebih lanjut dan lebih teliti semua bagian tubuh pasien, bagian depan dan bagian belakang pasien. Pada secondary survey ini dilakukan pemeriksaan neurologis lengkap termasuk mencatat Glasgow coma skale (GCS) dan dilakukan foto rontgen yang diperlukan. (Gadar medik indonesia, 2016)

Primary Survey (penilaian awal) adalah mengatur pendekatan ke klien sehingga klien segera dapat diidentifikasi dan tertanggulangi dengan efektif. Pemeriksaan primary survey (penilaian awal) berdasarkan standar A-B-C dan D-E, dengan airway (A: jalan nafas), breathing (B: pernafasan), circulation (C: sirkulasi), disability (D: ketidak mampuan), dan exposure (E: penerapan). Keperawatan gawat darurat merupakan pelayanan keperawatan yang komperhensif diberikan pada pasien dengan injuri akut atau sakit yang mengancam kehidupan. Sebagai seorang spesialis perawat gawat darurat harus menghubungkan pengetahuan dan keterampilan untuk menangani respon pasien pada resusitasi, syok, trauma, dan kegawatan yang mengancam jiwa lainnya, dan salah satu tempat pasien gawat darurat adalah di Instalasi Gawat Darurat (IGD) (Krisanty, 2009).

Berdasarkan data yang di himpun dari report kunjungan rumah sakit jumlah pasien yang datang ke IGD tahun 2013 adalah 624.000 orang, 2014 sejumlah 725.000 orang dan ditahun 2015 sampai bulan november berjumlah 534.000 orang. Sementara di sumatera utara jumlah orang yang datang ke IGD tahun 2013 yaitu 510.000 orang ,ditahun 2014675.000 orang serta di 2015 sampai bulan november berjumlah 357.000 orang. (profil kes sumut, 2014)

Di kota Medan sendiri jumlah pasien yang datang ke IGD tahun 2013 adalah 252.100 orang dan tahun 2014385.000 orang serta sampai bulan november 2015 berjumlah 260.000 orang. Dimana hampir sepertiganya pasien yang datang dengan ke IGD dalam keadaan darurat yang memerlukan bantuan hidup dasar. (profil kes medan, 2013)

Perawat adalah anggota tim kesehatan yang paling lama kontak dengan pasien, sehingga di harapkan perawat harus mampu membela hak-hak pasien. Perawat bertanggung jawab meningkatkan kesehatan, pencegahan penyakit, penyembuhan, pemulihan serta pemeliharaan kesehatan dengan penekanan kepada upaya pelayanan kesehatan utama sesuai wewenang, tanggung jawab dan etika profesi keperawatan. Dalam memberikan pelayanan kesehatan perawat dituntut untuk lebih profesional agar kualitas pelayanan kesehatan yang diberikan semakin meningkat. Perawat dituntut memberikan pelayanan yang cepat, tepat, dan cermat dengan tujuan mendapatkan kesembuhan tanpa kecacatan. Oleh karena itu perawat perlu membekali dirinya dengan pengetahuan dan perlu meningkatkan keterampilan yang spesifik yang berhubungan dengan kasus-kasus kegawatdaruratan utamanya kasus kegawatan pernafasan dan kegawatan jantung. (Maryuani, 2009)

Dari hasil penelitian studi di Rumah Sakit Daerah Kabupaten Makassar didapat pada bulan Desember 2014 diketahui bahwa pasien masuk ke Instalasi Gawat Darurat sebanyak 102 pasien, diantaranya $10 \%$ penyakit gawatdarurat dan 20-30\% kecelakaan lalu lintas (IGD, 2014 ). Berdasarkan pengamatan dari peneliti, perawat di IGD tersebut tidak melakukan tindakan pengkajian primary survey (penilaian awal) pada kasus kegawatdaruratan.

Berdasarkan survei pendahuluan yang dilaksanakan di bidang keperawatan RSUD Dr. Pirngadi Medan didapat data bahwa sudah banyak perawat yang telah mendapat pelatihan BLS, berupa pelatihan BTCLS dan PPGD. Dari wawancara singkat bersama kepala bidang keperawatan RSUD Dr. Pirngadi Medan dalam melakukan primery survey (penilaian awal) pada pasien yang mengalami kegawatdaruratan menggunakan metode AHA 2015 yaitu A-B-C dan D-E dengan, airway (A: jalan nafas), breathing (B: pernafasan), circulation (C: sirkulasi), disability (D: ketidak mampuan), dan exposure (E: penerapan). Berdasarkan data yang di dapat pada rekam medik pasien yang datang ke IGD pada tahun 2015 berjumlah 20.360 pasien, dan tahun 2016 dari januari desember berjumlah 19.319. Berdasarkan latar belakang tersebut, penulis merasa tertarik untuk mengangkat penelitian tentang "Pengetahuan Perawat Tentang Primary Survey (penilaian awal) pada Pasien Gawat Darurat Di Instalasi Gawat Darurat RSUD.Dr.Pirngadi Medan. 


\section{METODE}

Penelitian ini dilakukan di IGD RSUD dr. Pirngadi Medan tahun 2017 pada bulan Januari sampai Juli 2017. Dalam penelitian ini menggunakan adalah deskriptif. Dalam hal ini, peneliti melihat gambaran pengetahuan perawat tentang primary survey (penilaian awal) pada pasien gawat darurat dengan pendekatan cross sectional, dimana pengukuran atau pengamatan dilakukan pada waktu bersamaan (sekali waktu).

\section{POPULASI DAN SAMPLE}

Adapun yang menjadi Populasi pada penelitian ini adalah perawat yang bertugas di ruangan IGD RSUD dr. Pirngadi Medan yaitu berjumlah 30 orang. Teknik pengambilan sampel dalam penelitian ini adalah total sampling. Total sampling adalah teknik pengambilan sampel dimana jumlah sampel sama dengan jumlah populasi. Alasan mengambil total sampling, karena jumlah populasi yang kurang dari 100 seluruh populasi dijadikan sample penelitian seluruhnya. Adapun yang menjadi sampel dalam penelitian ini adalah seluruh perawat yang bertugas di ruang IGD RSUD dr. Pirngadi Medan (30 orang).

\section{HASIL}

Hasil penelitian ini dianalisis berdasarkan kuesioner yang diisi oleh 30 responden dan disajikan dalam bentuk tabel distribusi frekuensi pada setiap variabel yaitu pengetahuan, pendidikan, umur, masa kerja. Berikut ini distribusi frekuensi dari setiap variabel yang telah di analisa.

Tabel 4.1 Distribusi Frekuensi Pengetahuan Responden Terhadap Pengetahuan Perawat Tentang Primary Survey (Penilaian Awal) Di Instalasi Gawat Darurat RSUD Dr.Pirngadi Medan Tahun 2017

\begin{tabular}{rlll}
\hline No & Pengetahuan & Frekuensi & Persentase \\
\hline 1 & Baik & 19 & 63,3 \\
2 & Cukup & 11 & 36,7 \\
\hline & Jumlah & 30 & 100,0 \\
\hline
\end{tabular}

Tabel 4.2 Distribusi $\begin{array}{lr}\text { Frekuensi } & \text { Responden } \\ \text { Pendidikan } & \text { Terhadap }\end{array}$ Berdasarkan Pendidikan Terhadap Pengetahuan Perawat Tentang Primary Survey (Penilaian Awal) Di Instalasi Gawat Darurat RSUD Dr.Pirngadi Medan Tahun 2017

\begin{tabular}{llll}
\hline No & Pendidikan & Frekuensi & Persentase \\
\hline 1 & D III & 18 & 60,0 \\
2 & S I & 12 & 40,0 \\
\hline & Jumlah & 30 & 100 \\
\hline
\end{tabular}

Tabel 4.3 Distribusi $\quad$ Frekuensi $\quad$ Responden

Berdasarkan Umur Terhadap

Pengetahuan Perawat Tentang Primary

Survey (Penilaian Awal) Di Instalasi

Gawat Darurat RSUD Dr.Pirngadi

Medan Tahun 2017

\begin{tabular}{llll}
\hline No & Umur & Frekuensi & Persentase \\
\hline 1 & $26-30$ tahun & 4 & 13,3 \\
2 & $31-35$ tahun & 10 & 33,3 \\
3 & $36-39$ tahun & 9 & 30,0 \\
4 & $>40$ tahun & 7 & 23,3 \\
\hline & Jumlah & 30 & 100,0 \\
\hline
\end{tabular}

Tabel 4.4 Distribusi $\quad$ Frekuensi $\quad$ Responden

Berdasarkan Masa Kerja Terhadap

Pengetahuan Perawat Tentang Primary

Survey (Penilaian Awal) Di Instalasi Gawat

Darurat RSUD Dr.Pirngadi Medan Tahun 2017

\begin{tabular}{llll}
\hline No & Masa kerja & Frekuensi & Persen \\
\hline 1 & 1-5 tahun & 14 & 46,7 \\
2 & 6-10 tahun & 11 & 36,7 \\
3 & $>10$ tahun & 5 & 16,7 \\
\hline & JUMLAH & 30 & 100,0 \\
\hline
\end{tabular}

Berdasarkan tabel 4.1 di atas dapat diketahui bahwa mayoritas perawat di instalasi gawat darurat RSUD Dr. pirngadi medan tahun 2017 berpengetahuan baik dalam primary survey (penilaian awal) yaitu sebanyak 19 responden $(63,3 \%)$, pengetahuan cukup sebanyak 11 responden $(36,7 \%)$.

Tabel 4.4 di atas dapat diketahui bahwa mayoritas perawat di instalasi gawat darurat RSUD Dr.pirngadi medan tahun 2017 memiliki masa kerja 1-5 tahun sebanyak 14 orang $(46,7 \%)$, dan masa kerja $>10$ tahun sebanyak 5 orang $(16,7 \%)$.

Tabel 4.5 Distribusi Tabulasi Silang Pengetahuan Perawat Berdasarkan Pendidikan Tentang Primary Survey (Penilaian awal) Di Instalasi Gawat Darurat RSUD Dr.Pirngadi Medan Tahun 2017

\begin{tabular}{|c|c|c|c|}
\hline \multirow{3}{*}{ Pendidikan } & \multicolumn{2}{|c|}{ Pengetahuan } & \multirow[b]{2}{*}{ Total } \\
\hline & Baik & Cukup & \\
\hline & f $\%$ & f $\%$ & f $\%$ \\
\hline D III & $738,9 \%$ & $1161.1 \%$ & $18 \quad 100 \%$ \\
\hline S I & $12100 \%$ & $00 \%$ & $12100 \%$ \\
\hline Total & 1963,3 & $1136,6 \%$ & $30100 \%$ \\
\hline
\end{tabular}

Data Tabel 4.5 diatas dapat diketahui bahwa mayoritas responden yang memiliki tingkat pendidikan S I keperawatan berpengetahuan baik sebanyak 12 responden (100\%), Responden yang berpendidikan D III keperawatan berpengetahuan baik sebanyak 7 responden $(38,9 \%)$. berpengetahuan cukup sebanyak 11 responden $(61,1 \%)$. 
Tabel 4.6 Distribusi Tabulasi Silang Pengetahuan Perawat Berdasarkan Umur Dalam Primary Survey (Penilaian awal) Di Instalasi Gawat Darurat RSUD Dr.Pirngadi Medan Tahun 2017

\begin{tabular}{|c|c|c|c|}
\hline \multirow{2}{*}{ Umur } & \multicolumn{2}{|c|}{ Tingkat pengetahuan } & \multirow{2}{*}{$\begin{array}{l}\text { Total } \\
\text { f } \%\end{array}$} \\
\hline & $\begin{array}{c}\text { Baik } \\
\text { f } \%\end{array}$ & $\begin{array}{l}\text { Cukup } \\
\text { f \% }\end{array}$ & \\
\hline $\begin{array}{l}26-30 \\
\text { tahun }\end{array}$ & $375,0 \%$ & $125,0 \%$ & $4100 \%$ \\
\hline $\begin{array}{l}31-35 \\
\text { tahun }\end{array}$ & $6 \quad 60,0 \%$ & $4 \quad 40,0 \%$ & $10100 \%$ \\
\hline $\begin{array}{l}36-39 \\
\text { tahun }\end{array}$ & $5 \quad 55,6 \%$ & $4 \quad 44,4 \%$ & $9100 \%$ \\
\hline $\begin{array}{ll}> & 40 \\
\text { tahun }\end{array}$ & $571,4 \%$ & $228,6 \%$ & $7100 \%$ \\
\hline Total & $1963,3 \%$ & $1136,6 \%$ & $30100 \%$ \\
\hline
\end{tabular}

Tabel 4.6 Tabel di atas dapat diketahui bahwa mayoritas responden yang berumur 26-30 tahun berpengetahuan baik sebanyak 3 responden $(75,0 \%)$. Responden yang berumur 36-39 tahun berpengetahuan baik sebanyak 5 responden $(55,6 \%)$, berpengetahuan cukup sebanyak 4 responden $(44,4 \%)$.

Tabel 4.7 Distribusi Tabulasi Silang Pengetahuan Perawat Berdasarkan Masa Kerja Dalam Primary Survey (Penilaian awal) Di Instalasi Gawat Darurat RSUD Dr.Pirngadi Medan Tahun 2017

\begin{tabular}{|c|c|c|c|}
\hline \multirow{3}{*}{$\begin{array}{l}\text { Masa } \\
\text { Kerja }\end{array}$} & \multicolumn{3}{|c|}{ Pengetahuan } \\
\hline & Baik & Cukup & Jumlah \\
\hline & f $\%$ & f $\%$ & $\%$ \\
\hline $1-5$ thn & $535,7 \%$ & $964,3 \%$ & $11 \quad 100 \%$ \\
\hline 6-10 thn & $981,8 \%$ & $218,2 \%$ & $11100 \%$ \\
\hline$>10$ thn & $5100 \%$ & $0 \quad 0 \%$ & $5100 \%$ \\
\hline Jumlah & $1963,3 \%$ & $1136,6 \%$ & $30100 \%$ \\
\hline
\end{tabular}

Tabel 4.7 diatas dapat diketahui bahwa mayoritas responden yang memiliki masa kerja $>10$ tahun tahun berpengetahuan baik sebanyak 5 responden (100\%), berpengetahuan cukup tidak ada dijumpai (0\%). Responden yang memiliki masa kerja 1-5 tahun berpengetahuan cukup sebanyak 9 responden $(64,3 \%)$

\section{PEMBAHASAN}

\section{Pengetahuan}

Hasil penelitian menunjukkan bahwa dari 30 orang yang menjadi responden, mayoritas responden yang bertugas di ruang IGD memiliki pengetahuan yang baik tentang primary survey (penilaian awal), yaitu sebanyak 19 responden $(63,3 \%)$, namun masih ada responden yang pengetahuan cukup sebanyak 11 responden $(36,7 \%)$. Hasil penelitian ini sesuai dengan hasil penelitian Aziz Nur Fathoni, 2014 di RSUD Dr.Soediran dari 20 responden yang berpengetahuan baik sebanyak 15 responden (75\%), dan berpengetahuan cukup 5 responden (25\%), hal itu sesuai dengan pendapat sesuai referensi.

Pengetahuan adalah merupakan hasil "tahu" dan ini terjadi setelah orang mengadakan penginderaan terhadap suatu obyek tertentu. Penginderaan terhadap obyek melalui panca indra manusia yakni penglihatan, pendengaran, penciuman, rasa dan raba dengan sendiri. Pada waktu penginderaan sampai menghasilkan pengetahuan tersebut sangat dipengaruhi oleh intensitas perhatian persepsi terhadap obyek. Faktor-faktor yang mempengaruhi pengetahuan adalah pendidikan, pekerjaan, umur, lingkungan dan sosial budaya (Wawan \& Dewi, 2011).

\section{Pendidikan}

Hasil penelitian menunjukkan bahwa mayoritas perawat berpendidikan D III sebanyak 18 responden $(60,0 \%)$, dan S I sebanyak 12 responden $(40,0 \%)$. Hasil penelitian ini sesuai dengan hasil penelitian Ferawati, 2014 di RSUD. Dr.Mahfud mengatakan bahwa dari 30 responden, 24 responden $(80 \%)$ berpendidikan DIII keperawatan dan 6 responden $(20 \%)$ berpendidikan SI keperawatan. Hal itu sesuai dengan pendapat sesuai referensi.

Pendidikan berarti bimbingan yang diberikan seseorang terhadap perkembangan orang lain menuju kearah cita-cita tertentu yang menentukan manusia untuk berbuat dan mengisi kehidupan untuk mencapai keselamatan dan kebahagiaan. Pendidikan diperlukan untuk mendapat informasi misalnya hal-hal yang menunjang keselamatan sehingga dapat meningkatkan kualitas hidup. Pendidikan dapat mempengaruhi seseorang termasuk juga perilaku seseorang untuk sikap berperan serta dalam pembangunan, pada umumnya makin tinggi pendidikan seseorang makin mudah menerima informasi (Nursalam, 2003).

\section{Umur}

Hasil penelitian menunjukkan bahwa mayoritas perawat di instalasi gawat darurat RSUD Dr. Pirngadi Medan berumur 31-35 tahun sebanyak 10 responden (33,3\%), berumur 36-39 tahun sebanyak 9 responden $(30,0 \%)$, berumur $>40$ tahun sebanyak 7 orang $(23,3 \%)$, dan berumur 26-30 tahun sebanyak 4 orang (13,3\%). Hasil penelitian ini sesuai dengan hasil penelitian Fahmi, 2016 di RSUD. Dr.pirngadi medan mengatakan bahwa mayoritas perawat di instalasi gawat darurat berumur 31-35 tahun sebanyak 11 orang (35\%), berumur 36-39 tahun 7 responden $(22,6 \%)$, responden yang berumur 26-30 tahun 5 responden $(16,1 \%)$, dan hanya 8 orang yang berumur $>40$ tahun $(25,8 \%)$. Hal itu sesuai dengan pendapat sesuai referensi.

Usia adalah umur individu yang terhitung mulai saat dilahirkan sampai berulang tahun. Semakin cukup umur, tingkat kematangan dan kekuatan seseorang akan lebih matang dalam berfikir dan bekerja. Dari segi kepercayaan masyarakat seseorang yang lebih dewasa dipercaya dari orang yang belum tinggi kedewasaannya. Hal ini akan sebagai dari 
pengalaman dan kematangan jiwa (Wawan \& Dewi, 2011).

\section{Masa Kerja}

Dari hasil penelitian tabel 4.4 dapat diketahui bahwa mayoritas perawat di instalasi gawat darurat RSUD Dr. Pirngadi Medan tahun 2017 memiliki masa kerja 1-5 tahun sebanyak 14 orang $(46,7 \%)$, masa kerja 6-10 tahun sebanyak 11 orang $(36,7)$, dan masa kerja $>10$ tahun sebanyak 5 orang $(16,7 \%)$. Hasil penelitian ini sesuai dengan hasil penelitian Fahmi 2016, di RSUD Dr.pirngadi medan mengatakan bahwa responden yang memiliki masa kerja $<1$ tahun sebanyak 1 responden (3,2\%), yang berumur 1-5 tahun sebanyak 10 orang (32,3\%), masa kerja 6-10 tahun sebanyak 13 orang $(41,9 \%)$, dan masa kerja $>10$ tahun sebanyak 7 orang $(22,6 \%)$. Hal itu sesuai pendapat sesuai dengan referensi.

Masa kerja seseorang dapat memengaruhi pengetahuan tentang sesuatu hal, semakin lama ia bekerja maka semakin banyak pengalaman yang didapat saat menjalankan masa kerja sehingga semakin bertambah pula pengetahuan seseorang dari pengalaman yang telah dialaminya (Aziz Alimul, 2001).

\section{Tingkat pengetahuan perawat berdasarkan pendidikan}

Hasil penelitian menunjukkan bahwa mayoritas responden berpengetahuan baik berpendidikan S I sebanyak 12 responden (100\%), dan mayoritas responden yang berpengetahuan kurang yaitu berpendidikan D III sebanyak 11 responden $(61,1 \%)$. Hal sesuai dengan hasil penelitian yang dilakukan oleh Aziz, 2014 di instalasi gawat darurat RSUD Dr.Soediran Mangun Sumarso tentang pengetahuan perawat dalam pelaksanaan primary survey didapatkan hasil bahwa dari 20 responden yang diteliti mayoritas responden yang berpengetahuan baik sebanyak 13 responden $(57,5 \%)$ berpendidikan SI keperawatan dan mayoritas responden yang berpengetahuan kurang sebanyak 7 responden $(42,5 \%)$ berpendidikan DIII keperawatan. Dari penelitian menunjukkan bahwa semakin tinggi pendidikan seseorang, pengetahuan responden semakin baik, hal ini terdapat pada responden yang berpendidikan SI.

Hal ini juga sesuai dengan pendapat Notoadmojo bahwa, pendidikan dapat mempengaruhi seseorang termasuk juga perilaku seseorang untuk sikap berperan serta dalam pembangunan. pada umumnya makin tinggi pendidikan seseorang makin mudah menerima informasi dan pengetahuan yang dimiliki semakin baik. Hasil penelitian yang di dapat bahwa mayoritas yang berpengetahuan baik yaitu responden yang berpendidikan S I keperawatan, peneliti berasumsi bahwa hal ini terjadi karena baiknya materi yang didapatkan yang berhubungan dengan primary survey (penilaian awal), dan diaplikasikan dengan baik selama masa pendidikan. Dengan demikian, asumsi peneliti dan hasil yang didapat sejalan dengan teori yang ada (Notoadmojo, 2011).

\section{Tingkat pengetahuan perawat berdasarkan umur}

Berdasarkan tabel 4.6 mayoritas responden yang berpengetahuan baik pada usia 26-30 tahun 3 responden $(75,0 \%)$, namun terjadi penurunan tingkat pengetahuan baiknya pada usia $>40$ tahun 5 responden $(71,4 \%)$. Hal sesuai dengan penelitian yang dilakukan oleh Bahar, 2013 tentang gambaran tingkat pengetahuan perawat dalam penangan penilaian awal di ruang gawat darurat di RSUD Padjonga Daengale bahwa hasil yang didapatkan dari 40 responden, mayoritas memiliki umur 36-45 tahun (45\%) berpengetahuan baik, dan mayoritas responden yang memiliki umur 25-30 tahun berpengetahuan kurang. Dari hasil penelitian menunjukkan bahwa hal tersebut bertentangan dengan penelitian yang dilakukan oleh peneliti terdapat bahwa umur $>40$ tahun pengetahuan kurang, karena menurut teori dan penelitian yang dilakukan oleh Bahar, 2013 semakin lama umur seseorang, pengetahuan juga semakin baik.

Penelitian yang dilakukan peneliti mendapatkan hasil bahwa responden yang berumur $>40$ tahun berpengetahuan baik 5 responden $(71,4 \%)$, berpengetahuan cukup sebanyak 2 responden $(28.6 \%)$. Hal ini dapat disebabkan karena IQ seseorang akan menurun sejalan dengan bertambahnya usia atau perkembangan ilmu yang tidak diperbaharui, khususnya pada beberapa kemampuan misalnya penilaian primary survey dan pengetahuan umum.

Hasil diatas tidak sesuai dengan teori Notoadmodjo, yang mengatakan bahwa umur berpengaruh terhadap pengetahuan seseorang. Semakin bertambah umur seseorang maka pengetahuannya semakin membaik. Ini terjadi akibat pematangan fungsi organ. Pada aspek psikologis dan mental taraf berfikir seseorang semakin matang dan dewasa (Notoadmodjo, 2011)

Berdasarkan teori, Umur adalah lamanya hidup seseorang dalam tahun yang dihitung sejak dilahirkan. Semakin tinggi umur seseorang, maka semakin bertambah pula ilmu atau pengetahuan yang dimiliki karena pengetahuan seseorang diperoleh dari pengalaman sendiri maupun pengalaman yang diperoleh dari orang lain. Semakin tinggi umur individu maka pengetahuan yang dimiliki semakin baik, hal ini dikarenakan semakin banyak informasi dan pengalaman yang didapat (Notoadmodjo 2011).

\section{Tingkat pengetahuan perawat berdasarkan masa kerja \\ Dari tabel 4.7 di atas dapat kita ketahui} bahwa mayoritas responden dengan pengetahuan baik dalam primary survey (penilaian awal) yaitu masa kerja $>10$ tahun sebanyak 5 responden (100\%), pengetahuan cukup paling tinggi dijumpai pada responden masa kerja 1- 5 tahun sebanyak 9 responden $(64,3 \%)$, sedangkan pengetahuan kurang tidak dijumpai. Hal sesuai dengan penelitian yang dilakukan Suniarti, 2013 tentang pengetahuan perawat tentang penilaian awal pada pasien gawat daruat di instalasi 
gawat daruat bahwa dari 45 responden yang diteliti, mayoritas responden yang berpengetahuan baik memiliki masa kerja >10 tahun yaitu sebanyak 28 responden $(62,2 \%)$, mayoritas responden yang berpengetahuan kurang yaitu responden yang memiliki masa kerja > 6-10 tahun yaitu sebanyak 7 responden $(15,6 \%)$. Dari penelitian menunjukkan bahwa semakin tinggi masa kerja seseorang, pengetahuan responden semakin baik, hal ini terdapat pada responden yang masa kerja $>10$ tahun.

Hal ini juga sesuai dengan pendapat Notoadmojo, yang menyatakan bahwa semakin lama seseorang bekerja maka pengalaman yang dimiliki seseorang akan semakin matang. Dengan demi kian hasil penelitian yang didapatkan oleh peneliti sejalan dengan teori. Dari hasil penelitian ini, didapatkan bahwa mayoritas responden yang berpengetahuan baik yaitu, responden yang pengalaman kerjanya $>10$ tahun. Peneliti beramsumsi bahwa hal ini diakibatkan oleh semakin lama seseorang bekerja maka semakin terpapar dengan informasi yang berhubungan dengan primary survey (penilaian awal) dan semakin sering pula diaplikasikan dalam pelayanannya di instalasi gawat darurat. Dengan demikian, asumsi peneliti dan hasil penelitian sejalan dengan teori yang ada.

\section{SIMPULAN}

Responden yang berpengetahuan baik sangat dipengaruhi oleh umur dan pendidikan. Dimana semakin tinggi pendidikan yang dimiliki oleh responden maka pengetahuan yang dimiliki semakin baik, dan semakin lama masa kerja yang dimiliki responden maka pengetahuan yang dimiliki semakin baik pula.

Penelitian yang dilakukan oleh peneliti yang berkaitan dengan dimana semakin tua umur responden maka pengetahuan yang

Sebagai bahan masukan bagi rumah sakit untuk lebih meningkatkan sumbar daya manusia kesehatan (perawat) sebagai dasar untuk memberikan pelayanan keperawatan yang prima dan humanis

Mengadakan suatu kajian ulang terhadap pengetahuan dan keterampilan perawat dalam primary survey (penilaian awal) secara objektif.

Merencanakan suatu program peningkatan pengetahuan dan keterampilan perawat antara lain dengan mengadakan suatu pelatihan

\section{DAFTAR PUSTAKA}

Arikunto. 2013. Prosedur Penelitian. Jakarta: Rineka Cipta. Badan Intelijen Nasional. 2013. Laporan Hasil Daftar Angka Kematian Manusia.
Bolk, dkk. 2007. http://. Klasifikasi Pemberian Label. Diunduh tanggal 20 Februari 2017.

Darwis, dkk. 2005. http://. Triase Pasien Gawat Darurat. diunduh tanggal 2 Februari 2017.

Depkes, 2009. Laporan Hasil Riset Kesehatan Dasar (Riskesdas). Jakarta: Badan Penelitian Dan Pengembangan Depkes RI. www.Riskedas.com.

Fahmi. 2013. http://. Hubungan Masa Kerja Dengan Kualitas Kerja Dan Tingkat produktivitas diunduh tangal 2 Februari 2017.

Hidayat. 2008. Konsep Teori Perawat. Jakarta: Rineka Cipta.

Krisanty. 2009. Asuhan keperawatan gawat darurat. Trans indo media : Jakarta

Mantra. 2012. Pengukuran Pengetahuan Serta FaktorFaktor Pendukungnya. Jogjakarta: Flashbooks.

Musliha. 2014. Asuhan Keperawatan Gawat darurat. Jakarta: Rineka Cipta.

Notoatmodjo, Soekidjo. 2012. Metodelogi Penelitian Kesehatan. Jakarta: Rineka Cipta. 2012. Promosi Kesehatan Dan Perilaku Kesehatan. Jakarta: Rineka Cipta.

Maryuani. 2009. Peran Perawat Dalam Penanganan Pasien Gawat Darurat.

Muzaki. 2012 . http://. Gambaran Pengetahuan Perawat Tentang Primary survey diunduh tanggal 2 Februari 2017.

Osianus. 2013 . http://. Gambaran Pengetahuan Perawat Tentang Penilaian Glasglow Coma Scale diunduh tanggal 15 Desember 2015.

Philip, beverley, 2008. Pemantauan pasien kritis, Edisi Kedua, EMS : Jakarta

Profil Kesehatan Sumatera Utara. 2014 . http://. Propfil Kesehatan Sumatera Utara. diunduh tanggal 17 Februari 2017.

Profil Kesehatan Medan. 2013. http://. Propfil Kesehatan Medan. Di unduh tanggal 17 Februari 2017.

Politeknik Kesehatan Kemenkes Medan, 2016. Panduan Penyusunan Karya Tulis Ilmiah. Medan: politeknik kesehatan kemenkes medan. 